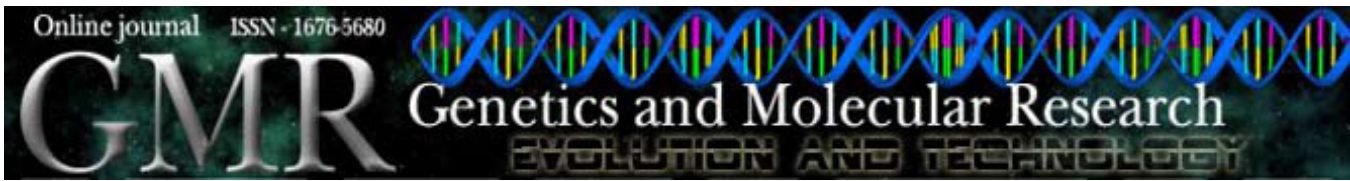

\title{
Enzymatic differences between the endophyte Guignardia mangiferae (Botryosphaeriaceae) and the citrus pathogen $G$. citricarpa
}

\author{
A.S. Romão ${ }^{1}$, M.B. Spósito ${ }^{2}$, F.D. Andreote ${ }^{1}$, J.L. Azevedo ${ }^{1}$ and \\ W.L. Araújo ${ }^{3}$ \\ ${ }^{1}$ Departamento de Genética, Escola Superior de Agricultura "Luiz de Queiroz", \\ Universidade de São Paulo, Piracicaba, SP, Brasil \\ ${ }^{2}$ Fundecitrus, Departamento Científico, Araraquara, SP, Brasil \\ ${ }^{3}$ Laboratório de Biologia Molecular e Ecologia Microbiana, NIB, \\ Universidade de Mogi das Cruzes, Mogi das Cruzes, SP, Brasil \\ Corresponding author: W.L. Araújo \\ E-mail: welingtonluiz@umc.br
}

Genet. Mol. Res. 10 (1): 243-252 (2011)

Received July 27, 2010

Accepted November 11, 2010

Published February 15, 2011

DOI 10.4238/vol10-1gmr952

\begin{abstract}
The endophyte Guignardia mangiferae is closely related to G. citricarpa, the causal agent of citrus black spot; for many years these species had been confused with each other. The development of molecular analytical methods has allowed differentiation of the pathogen $G$. citricarpa from the endophyte G. mangiferae, but the physiological traits associated with pathogenicity were not described. We examined genetic and enzymatic characteristics of Guignardia spp strains; G. citricarpa produces significantly greater amounts of amylases, endoglucanases and pectinases, compared to G. mangiferae, suggesting that these enzymes could be key in the development of citrus black spot. Principal component analysis revealed pectinase production as the main enzymatic characteristic that distinguishes these Guignardia species. We quantified the activities of pectin lyase, pectin methylesterase and endopolygalacturonase; $G$. citricarpa and G. mangiferae were found to have significantly different pectin lyase and endopolygalacturonase activities. The pathogen $G$. citricarpa is more effective in pectin degradation. We concluded that
\end{abstract}


there are significant physiological differences between the species $G$. citricarpa and G. mangiferae that could be associated with differences in pathogenicity for citrus plants.

Key words: Citrus black spot; Fungal-plant interaction; Pectinase; Hydrolytic enzymes; Endophyte; Citrus pathogen

\section{INTRODUCTION}

The endophyte Guignardia mangiferae A.J. Roy (anamorph: Phyllosticta capitalensis) has been confused with the citrus black spot pathogen G. citricarpa Kiely (anamorph: Phyllosticta citricarpa McAlpine) for many years. There are several reports of two morphologically similar species of Guignardia spp infecting citrus plants. These species differ with respect to their ability to cause citrus disease, growth in different culture media (Lee, 1969), and sequence of the internal transcribed spacer (ITS) (Meyer et al., 2001). Baayen et al. (2002) proved the occurrence of these two species in citrus, and described the endophytic one as G. mangiferae A.J. Roy. The development of molecular analytical methods has allowed differentiation of the citrus black spot pathogen from the endophytes (Bonants et al., 2003; Van Gent-Pelzer et al., 2007), but the physiological traits associated with pathogenicity have not yet been studied.

G. mangiferae has been reported as a ubiquitous endophyte and has been isolated from numerous plants (Baayen et al., 2002). G. citricarpa has a narrower host range, and has been isolated mostly from citrus species (Araújo et al., 2001; Glienke-Blanco et al., 2002; Durán et al., 2005). Besides the wider host range, the geographic distribution of $G$. mangiferae is also much wider than that of G. citricarpa and remarkably includes regions in which the disease caused by G. citricarpa has not been reported (Everett and ReesGeorge, 2006).

Any fungus that attempts to colonize a higher plant must contend with physical barriers of the host: surface waxes, cutin and the cell wall. One of the most conspicuous effects of microorganisms on the plant cell wall is enzymatic degradation (Walton, 1994) by the activity of fungal cell wall-degrading enzymes, which may facilitate fungal growth and provide the fungus with nutrients. In a number of systems, a strong correlation has been found between the presence of pectinolytic enzymes, disease symptoms, and virulence (Durrands and Cooper, 1988). Pectinases are a group of enzymes that catalyze degradation of the pectic polymers present in plant cell walls and render them more susceptible to further breakdown by other enzymes. Pectin-degrading enzymes have been reported as the first extracellular degradative enzymes produced during infection (Mankarios and Friend, 1980). Specifically, endopolygalacturonases (endoPGs) and pectin lyases (PL) have been proposed to have an important role in fungal pathogenicity (Wattad et al., 1995; Shieh et al., 1997; Ten Have et al., 1998; Rogers et al., 2000; Wagner et al., 2000; Yakoby et al., 2000; Garcia-Maceira et al., 2001; Basaran et al., 2007).

In this study, in order to understand the interaction between host plant and Guignardia spp, fungal strains were first classified as G. mangiferae or G. citricarpa by ITS15.8S-ITS2 sequence comparison. These species were then compared regarding production of amylases, cellulases and pectinases on solid medium, and pectinase activities were 
quantified. The results showed that G. mangiferae and G. citricarpa have significantly different abilities to produce hydrolytic enzymes, especially the pectinases, which may be associated with the strategy used by these species to infect, colonize and induce or not disease symptoms in citrus host plants.

\section{MATERIAL AND METHODS}

\section{Fungal isolates and culture methods}

A total of 36 isolates of Guignardia spp were used in the present study; some were from the laboratory of Microbial Genetics (ESALQ/USP, Piracicaba, Brazil), and the origins of the others are given in Table 1. The isolates were grown on potato dextrose agar (PDA; Merck) at $28^{\circ} \mathrm{C}$ for $10-20$ days.

\section{Molecular approach}

To extract genomic DNA, isolates were grown on PD for 10 days at $28^{\circ} \mathrm{C}$ without shaking. The mycelia were collected by filtration and ground in liquid nitrogen, and $4 \mathrm{~mL}$ lysis buffer (200 mM Tris-HCl, pH 8.0, $250 \mathrm{mM} \mathrm{NaCl}, 25 \mathrm{mM}$ EDTA, 1\% SDS) was added for each gram of mycelium. The mixture was incubated for $15 \mathrm{~min}$ at $70^{\circ} \mathrm{C}$, and DNA was purified by the standard phenol:chloroform method (Sambrook et al., 1989). The DNA was precipitated with $60 \%$ volume of isopropanol and pelleted by centrifugation at $14,000 \mathrm{~g}$ for $10 \mathrm{~min}$. The DNA was washed with $70 \%$ ethanol, dried, and dissolved in TE buffer $(10 \mathrm{mM}$ Tris-HCl, pH 7.6, 1 mM EDTA, $\mathrm{pH} 8.0$ ). DNA integrity was verified by electrophoresis on a $0.8 \%$ agarose gel.

The region of ribosomal DNA containing the ITS1-5.8S-ITS2 fragments was amplified by polymerase chain reaction (PCR) using the primers ITS-1 (5'-TCCGTAGGTGAACCTGCGG-3') and ITS-4 (5'-TCCTCCGCTTATTGATATGC-3'). PCRs were performed in a final volume of 50 $\mu \mathrm{L}$ containing $50 \mathrm{ng}$ DNA template, $0.2 \mathrm{mM}$ each dNTP, $0.2 \mu \mathrm{M}$ each primer, $3.7 \mathrm{mM} \mathrm{MgCl}$, $0.4 \mathrm{U}$ Taq DNA polymerase (Invitrogen, Brazil), $50 \mathrm{mM} \mathrm{KCl}$, and $20 \mathrm{mM}$ Tris- $\mathrm{HCl}, \mathrm{pH}$ 8.4. The reaction mixtures were incubated in a Perkin Elmer thermocycler with an initial denaturation step at $94^{\circ} \mathrm{C}$ for $5 \mathrm{~min}$, and then 32 cycles of $30 \mathrm{~s}$ at $94^{\circ} \mathrm{C}, 30 \mathrm{~s}$ at $55^{\circ} \mathrm{C}$ and $30 \mathrm{~s}$ at $72^{\circ} \mathrm{C}$, followed by a final extension at $72^{\circ} \mathrm{C}$ for $7 \mathrm{~min}$. The PCR products were purified with the UltraClean PCR Clean-up Kit (MoBio Laboratories Inc.) and sequenced using the ITS-4 primer at the University of Mogi das Cruzes, São Paulo, Brazil.

Nucleotide sequences were analyzed with BLAST (Altschul et al., 1990) and compared with representative Guignardia spp ITS sequences from GenBank (National Center for Biotechnology Information; NCBI), aligned and analyzed phylogenetically using the MEGA software version 3.1 (Kumar et al., 2004). Clustering was calculated by the neighbor-joining method with 1000 bootstrap replicates based on genetic distances calculated via the Jukes and Cantor model.

\section{Physiologic approach}

Semi-quantitative tests were performed on solid medium to evaluate the abilities of 
the fungi to produce amylases, endoglucanases (CMCase) and pectinases. For that, fragments of fungus grown on PDA $\left(5-\mathrm{mm}^{2}\right.$ plugs) for 10 days at $28^{\circ} \mathrm{C}$ were placed onto minimal medium (MM) (Pontecorvo, 1953) supplemented with $10 \mathrm{~g}$ starch, carboxymethyl cellulose or citric pectin. After 5 days of growth, the isolates were evaluated for pectinase and amylase (Hankin and Anagnostakis, 1975), and for endoglucanase (Teather and Wood, 1982). The enzymatic activity was estimated by the halo/colony diameter ratio, and three replicates were used in all analyses.

Quantitative tests were performed to evaluate the ability of G. citricarpa and G. mangiferae to degrade pectin. The enzymatic activities of PL, pectin methylesterase (PME), and endoPG were assessed by growing G. mangiferae (G1, G13, G16, 515, LRS36/99, 1F1, 1F2) and G. citricarpa (G8, G12, F22, L4-F6, 7LE10, LRS22/99, LRS34/98) for 5 days at $28^{\circ} \mathrm{C}$ in $30 \mathrm{~mL}$ liquid MM containing $10 \mathrm{~g} / \mathrm{L}$ citric pectin. The cultures were harvested and the cell-free supernatant of three replicates was analyzed. The protein concentration of the extracts was measured by the Bradford method (1976).

PL activity was quantified as the increase in absorbance at $235 \mathrm{~nm}$ after incubation of the extract for $45 \mathrm{~min}$ at $45^{\circ} \mathrm{C}$ with $2.5 \%$ pectin followed by the addition of $\mathrm{HCl}$ to a final concentration of $0.01 \mathrm{M}$. A molar extinction coefficient of 5550 (Albersheim, 1966) was used to calculate the PL activity. The endoPG activity was measured as the release of reducing groups from $0.1 \%(\mathrm{w} / \mathrm{v})$ polygalacturonic acid and quantified by the cyanoacetamide method (Gross, 1982). PME activity was determined by measuring the decrease in absorbance at $600 \mathrm{~nm}$ due to acid production during de-esterification of $4 \%$ pectin (Zamski and Peretz, 1996).

\section{Data analysis}

The production of hydrolytic enzymes was subjected to principal component analysis (PCA) using the Canoco 4.5 software (Ter Braak and Šmilauer, 2002). The first two principal components were plotted to visualize the grouping of samples. The Monte Carlo statistical test with 499 random permutations was used to obtain the P values of the factors.

The enzymatic data were analyzed using the statistical package SAS ${ }^{\circ}$ (1989-1996, SAS Institute Inc., Cary, USA). The enzymatic activity data were transformed using ( $\mathrm{x}+$ $0.5)^{1 / 2}$. All experiments were subjected to analysis of variance considering the homogeneity of variances. The Student $t$-test was used to compare the groups of isolates of G. mangiferae and G. citricarpa.

\section{RESULTS}

The phylogeny based on the ITS1-5.8S-ITS2 sequences revealed the clustering of the 36 Guignardia spp strains into two major groups (A and B) (Table 1, Figure 1). Group A was composed of 21 isolates obtained from healthy tissues of different hosts, where the fungus had been present endophytically, as well as G. mangiferae GenBank sequences. Group B included 14 isolates that originated from fruits and leaves with classical black spot symptoms, one isolate from Catharanthus roseus stem and G. citricarpa GenBank sequences. Both groups A and B were highly similar only to G. mangiferae and G. citricarpa, respectively. 


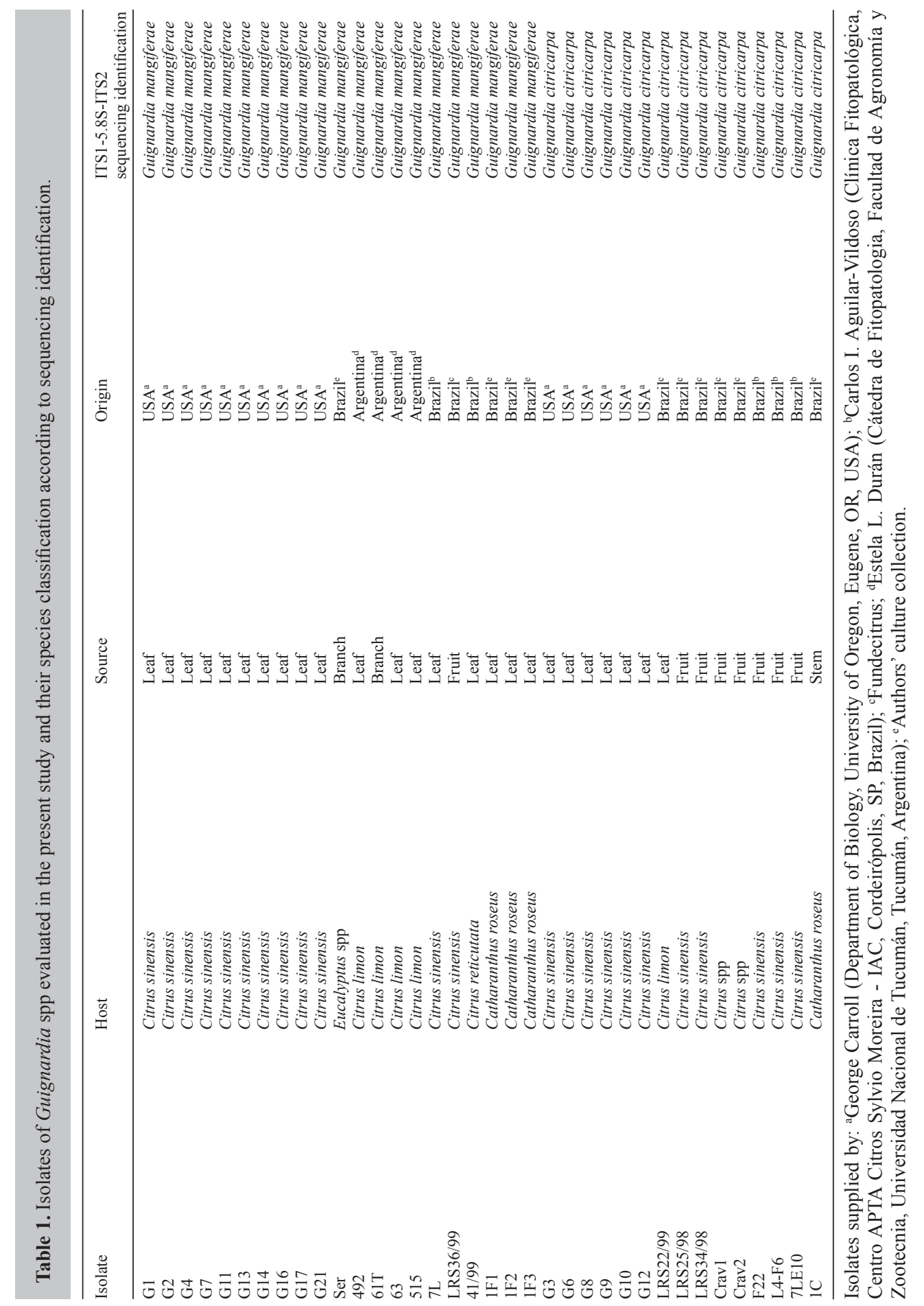

Genetics and Molecular Research 10 (1): 243-252 (2011) 
The enzymatic semi-quantitative tests performed on solid medium showed that G. citricarpa produced significantly greater amounts of amylases $(\mathrm{P}=0.0010)$, endoglucanases $(\mathrm{P}=0.0077)$ and pectinases $(\mathrm{P}<0.0001)$ than did G. mangiferae (Table 2). PCA (Figure 2), considering the production of hydrolytic enzymes, showed that pectinase production was the main factor discriminating the two species G. citricarpa and G. mangiferae.

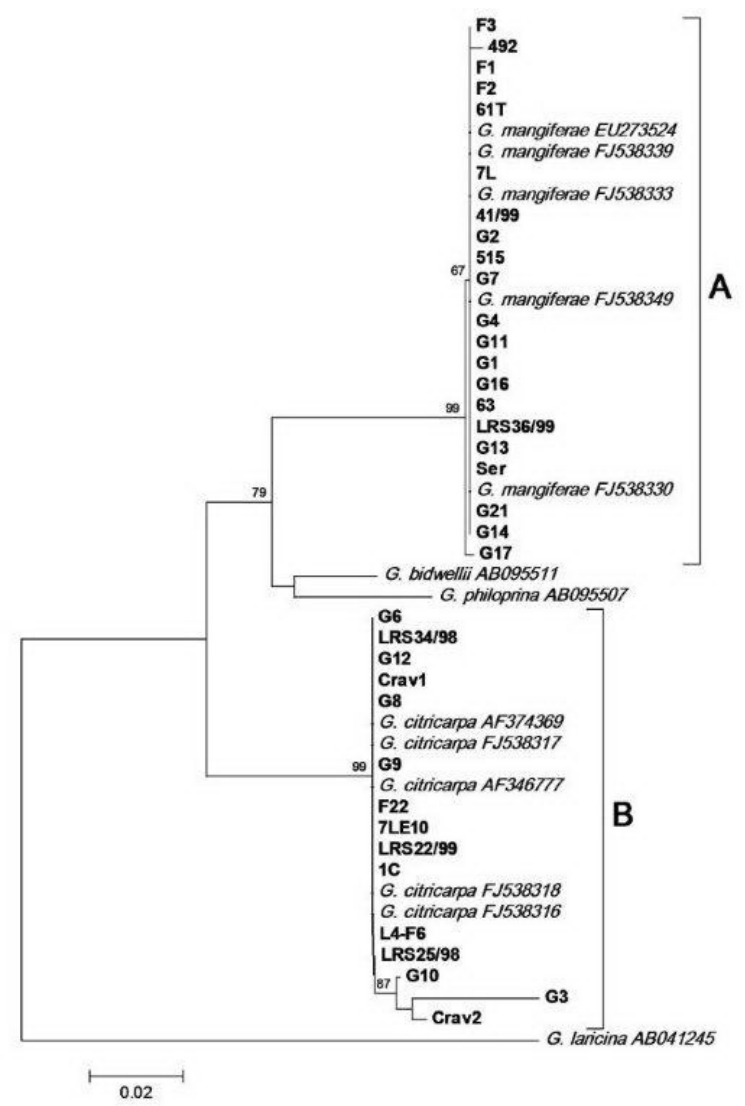

Figure 1. Phylogram with bootstrap values (1000 replicates) derived from DNA sequence data of the ITS region (ITS1-5.8S-ITS2) for the 36 Guignardia strains studied and 13 sequences of Guignardia species from GenBank. Group A represents the G. mangiferae isolates and group B represents the G. citricarpa isolates. The G. laricina sequence was included as the outgroup.

Table 2. Production of hydrolytic enzymes by Guignardia mangiferae and G. citricarpa showing the differences,
standard errors, and $t$-test results.
\begin{tabular}{lccccrr}
\hline Enzyme & \multicolumn{2}{c}{ Mean } & Estimate & Standard error & $t$ & $\mathrm{P}^{\mathrm{a}}$ \\
\cline { 2 - 7 } & G. mangiferae & G. citricarpa & & & & \\
\hline Amylase & 1.53 & 1.84 & -0.51 & 0.149 & -3.42 & 0.0010 \\
Endoglucanase & 1.18 & 1.42 & -0.32 & 0.115 & -2.74 & 0.0077 \\
Pectinase & 1.06 & 2.77 & -0.83 & 0.144 & -5.77 & $<0.0001$ \\
\hline
\end{tabular}

${ }^{a}$ Nominal significance level in the $t$-test for comparison. 


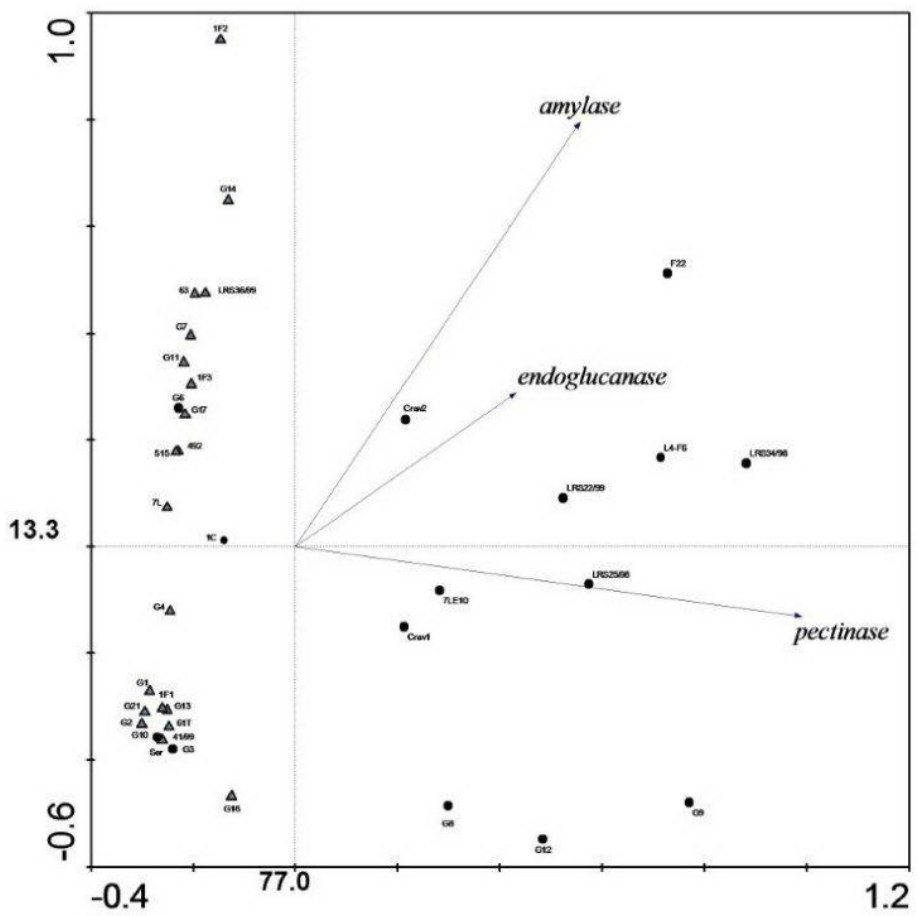

Figure 2. Principal component analysis (PCA) based on the production of hydrolytic enzymes (amylase, endoglucanase and pectinase) on solid media by Guignardia mangiferae and G. citricarpa isolates. Values in axes indicate the variance-explained axis.

The ability of the Guignardia spp to produce different pectinases was assessed on the basis of three activities: PL, PME and endoPG. The results showed that G. citricarpa and $G$. mangiferae had significantly different PL $(\mathrm{P}<0.0001)$ and endoPG $(\mathrm{P}=0.0335)$ activities, but no significant difference was observed for PME $(\mathrm{P}=0.1077)$ activity (Table 3$)$.

Table 3. Production of three pectinolytic enzymes (endopolygalacturonase, pectin methylesterase and pectin lyase) by Guignardia mangiferae and G. citricarpa showing the differences, standard errors, and $t$-test results.

\begin{tabular}{|c|c|c|c|c|c|c|}
\hline \multirow[t]{2}{*}{ Pectinolytic enzyme } & \multicolumn{2}{|c|}{ Mean } & \multirow[t]{2}{*}{ Estimate } & \multirow[t]{2}{*}{ Standard error } & \multirow[t]{2}{*}{$t$} & \multirow[t]{2}{*}{$\mathrm{P}^{\mathrm{a}}$} \\
\hline & G. mangiferae & G. citricarpa & & & & \\
\hline Endopolygalacturonase $^{\mathrm{b}}$ & 1.13 & 1.63 & 1.69 & 0.756 & 2.24 & 0.0335 \\
\hline Pectin methylesterase ${ }^{c}$ & 0.74 & 0.77 & -0.05 & 0.033 & -1.66 & 0.1077 \\
\hline Pectin lyase ${ }^{\mathrm{d}}$ & 5.79 & 6.68 & -11.58 & 2.450 & -4.73 & $<0.0001$ \\
\hline
\end{tabular}

${ }^{a}$ Nominal significance level in the $t$-test for comparison; ${ }^{b}$ One unit of enzymatic activity was defined as the amount of enzyme required to release $1 \mu \mathrm{mol}$ of reducing sugar groups per milliliter per minute; 'One unit of enzyme activity was defined as the ratio between absorbance $(600 \mathrm{~nm})$ and total protein per minute; ${ }^{\mathrm{d}}$ One unit of enzyme activity was defined as the amount of enzyme that produced $1 \mathrm{nmol}$ of unsaturated uronides per milliliter of culture extract per minute. 


\section{DISCUSSION}

There is an extensive literature describing the molecular and morphological differences that distinguish the two species of Guignardia that inhabit citrus plants (Meyer et al., 2001; Baayen et al., 2002; Bonants et al., 2003; Durán et al., 2005; Everett and Rees-George, 2006; Van Gent-Pelzer et al., 2007). However, there has been no report of the enzymatic aspects associated with species. In the present study, we evaluated the enzymatic profiles of $G$. mangiferae and G. citricarpa. The results showed that G. citricarpa strains produced significantly greater amounts of hydrolytic enzymes (Table 2) and that the main factor distinguishing the Guignardia species was the difference in the level of pectinase production (Figure 2). These data suggest that the level of pectinase production could be used to differentiate these two species. Further studies are required to establish the possible role of these enzymes in host-pathogen and host-endophyte interactions.

The differences in the level of production of pectinases suggest that these enzymes may have distinct roles during the interaction of the pathogen G. citricarpa and the endophyte G. mangiferae with citrus plants. G. citricarpa penetrates directly into citrus tissues, forms subcuticle mycelia and remains latent for 4-6 months (Timmer, 1999); after this period, injury is induced mainly in fruit, pectin-rich organs, showing that the pectinolytic enzymes are not involved primarily in either invasion or nutrition, but are related to disease symptoms. In the case of G. mangiferae, the pectinases may be important for endophytic colonization or even for the colonization of senescent and dead tissues. Interestingly, in the genus Colletotrichum a pectin lyase gene has been proposed to be fundamental to defining the fungus lifestyle, from endophytic mutualist to pathogen (Freeman and Rodriguez, 1993; Wattad et al., 1995; Redman et al., 1999; Yakoby et al., 2000).

The quantification of the enzymatic activity of three pectinases (PL, PME and endoPG) showed that G. citricarpa and G. mangiferae had significantly different levels of PL and endoPG activity, but similar levels of PME activity (Table 3). PL and endoPG depolymerize the pectin backbone, whereas PME alters the structure of the intact pectin backbone by catalyzing the hydrolysis of galacturonate methyl esters (Kester et al., 2000). This suggests that the lack of difference between G. citricarpa and G. mangiferae PME activity is probably due to the enzyme activity pattern; i.e., endoPG and PL act synergistically in the development of plant pathogenesis. The endoPGs are the first detectable enzymes secreted by phytopathogenic fungi when they are grown in vitro on plant cell walls and during the infection process (Johnston and Williamson, 1992). Evidence that polygalacturonases are involved directly in the pathogenic process has been provided by targeted mutagenesis in Aspergillus flavus (Shieh et al., 1997), Botrytis cinerea (Ten Have et al., 1998), Fusarium oxysporum (Garcia-Maceira et al., 2001), and Penicillium olsonii (Wagner et al., 2000). Likewise, Rogers et al. (2000) reported that the disruption of two PL genes drastically reduced the virulence of Nectria haematococca in peas (Pisum sativum). A long series of publications on production of lyase enzymes by pathogenic vs nonpathogenic Colletotrichum also showed that a single PL gene is essential for C. magna pathogenic abilities and is a pathogenicity factor required for the penetration and colonization of Colletotrichum species (Freeman and Rodriguez, 1993; Wattad et al., 1995; Redman et al., 1999; Yakoby et al., 2000). However, there are also reports on the disruption of endoPG and PL genes that show limited or no contribution to the pathogenic abilities of the pathogen (Bowen et al., 1995; Guo et al., 1995; Scott-Craig et al., 1990, 1998; Roncero et al., 2003). 
The conflicting results of the influence of these enzymes in fungal pathogenicity demonstrate the difficulties encountered in investigating these interactions and behaviors. It is worth noting that the disruption of a certain gene may have no detectable effect, because other genes can mask its inactivity.

The results of this study showed that these two species of Guignardia secrete significantly different levels of hydrolytic enzymes, especially pectinases. Therefore, G. citricarpa and G. mangiferae, which are closely related but interact differently with the same host, can be distinguished by both genetic and physiological features. Further studies, such as gene inactivation, are required to improve the understanding of the interactions of these two Guignardia species in citrus plants, and may contribute to providing new approaches to citrus black spot control.

\section{ACKNOWLEDGMENTS}

Research supported by CNPq/RHAE (Conselho Nacional de Desenvolvimento Científico e Tecnológico/Programa de Capacitação de Recursos Humanos para Atividades Estratégicas) and Fundecitrus (Fundo de Defesa da Citricultura). We thank Dr. E. Durán, Dr. G. Carroll and Dr. C.I. Aguilar-Vildoso for supplying some of the strains used in this study.

\section{REFERENCES}

Albersheim P (1966). Pectin lyase from fungi. Methods Enzymol. 8: 628-631.

Altschul SF, Gish W, Miller W, Myers EW, et al. (1990). Basic local alignment search tool. J. Mol. Biol. 215: 403-410.

Araújo WL, Maccheroni W Jr, Aguilar-Vildoso CI, Barroso PA, et al. (2001). Variability and interactions between endophytic bacteria and fungi isolated from leaf tissues of citrus rootstocks. Can. J. Microbiol. 47: 229-236.

Baayen RP, Bonants PJ, Verkley G, Carroll GC, et al. (2002). Nonpathogenic isolates of the citrus black spot fungus, Guignardia citricarpa, identified as a cosmopolitan endophyte of woody plants, G. mangiferae (Phyllosticta capitalensis). Phytopathology 92: 464-477.

Basaran P, Ozcan M, Denisov Y and Freeman S (2007). Elucidation of pectinolytic enzyme activities of a nonpathogenic watermelon pathogen mutant, Fusarium oxysporum f. sp. niveum M87. Austr. Plant Pathol. 36: 135-141.

Bonants PJM, Caroll GC, de Weerdt M, Van Brouwershaven IR, et al. (2003). Development and validation of a fast PCR based detection method for pathogenic isolates of the citrus black spot fungus, Guignardia citricarpa. Eur. J. Plant Pathol. 109: 503-513.

Bowen JK, Templeton MD, Sharrock KR, Crowhurst RN, et al. (1995). Gene inactivation in the plant pathogen Glomerella cingulata: three strategies for the disruption of the pectin lyase gene pnlA. Mol. Gen. Genet. 246: 196-205.

Bradford MM (1976). A rapid and sensitive method for the quantitation of microgram quantities of protein utilizing the principle of protein-dye binding. Anal. Biochem. 72: 248-254.

Durán EL, Ploper LD, Ramallo JC, Grandi RAP, et al. (2005). The foliar fungal endophytes of Citrus limon in Argentina. Can. J. Bot. 83: 350-355.

Durrands PK and Cooper RM (1988). The role of pectinases in vascular wilt disease as determined by defined mutants of Verticillium albo-altrum. Physiol. Mol. Plant Pathol. 32: 363-371.

Everett KR and Rees-George J (2006). Reclassification of an isolate of Guignardia citricarpa from New Zealand as Guignardia mangiferae by sequence analysis. Plant Pathol. 55: 194-199.

Freeman S and Rodriguez RJ (1993). Genetic conversion of a fungal plant pathogen to a nonpathogenic, endophytic mutualist. Science 260: 75-78.

Garcia-Maceira FI, Di Pietro A, Huertas-Gonzalez MD, Ruiz-Roldan MC, et al. (2001). Molecular characterization of an endopolygalacturonase from Fusarium oxysporum expressed during early stages of infection. Appl. Environ. Microbiol. 67: 2191-2196.

Glienke-Blanco C, Aguilar-Vildoso CI, Vieira MLC, Barroso PAV, et al. (2002). Genetic variability in the endophytic fungus Guignardia citricarpa isolated from citrus plants. Genet. Mol. Biol. 25: 251-255.

Gross KC (1982). A rapid and sensitive method for assaying polygalacturonase using 2-cyanoacetamide. HortScience 17: 933-934. 
Guo W, Gonzalez-Candelas L and Kolattukudy PE (1995). Cloning of a novel constitutively expressed pectate lyase gene pelB from Fusarium solani f. sp. pisi (Nectria haematococca, mating type VI) and characterization of the gene product expressed in Pichia pastoris. J. Bacteriol. 177: 7070-7077.

Hankin L and Anagnostakis SL (1975). The use of solid media for detection of enzyme production by fungi. Mycologia 67: 597-607.

Johnston DJ and Williamson B (1992). Purification and characterization of four polygalacturonases from Botrytis cinerea. Mycol. Res. 96: 343-349.

Kester HC, Benen JA, Visser J, Warren ME, et al. (2000). Tandem mass spectrometric analysis of Aspergillus niger pectin methylesterase: mode of action on fully methyl-esterified oligogalacturonates. Biochem. J. 346 (Pt 2): 469-474.

Kumar S, Tamura K and Nei M (2004). MEGA3: Integrated software for Molecular Evolutionary Genetics Analysis and sequence alignment. Brief. Bioinform. 5: 150-163.

Lee YS (1969). Pathogenicity of different isolates of Guignardia citricarpa Kiely from various sources of Ponkan fruit. J. Taiwan Agric. Res. 18: 45-50.

Mankarios AT and Friend J (1980). Polysaccharide degrading enzymes of Botrytis allii and Sclerotium cepivorum. Enzyme production in culture and the effect of the enzymes on isolated onion cell walls. Physiol. Plant Pathol. 17: 93-104.

Meyer L, Slippers B, Korsten L, Kotzé JM, et al. (2001). Two distinct Guignardia species associated with citrus in South Africa. S. Afr. J. Sci. 97: 191-194.

Pontecorvo G (1953). The Genetics of Aspergillus nidulans. In: Advances in Genetics (Demerec M, ed.). Academic Press Inc., New York, 141-238.

Redman RS, Ranson JC and Rodriguez RJ (1999). Conversion of the pathogenic fungus Colletotrichum magna to a nonpathogenic endophytic mutualist by gene disruption. Mol. Plant Microbe Interact. 12: 969-975.

Rogers LM, Kim YK, Guo W, Gonzalez-Candelas L, et al. (2000). Requirement for either a host- or pectin-induced pectate lyase for infection of Pisum sativum by Nectria hematococca. Proc. Natl. Acad. Sci. U. S. A. 97: 9813-9818.

Roncero MIG, Hera C, Ruiz-Rubio M, García-Maceira FI, et al. (2003). Fusarium as a model for studying virulence in soilborne plant pathogens. Physiol. Mol. Plant Pathol. 62: 87-98.

Sambrook J, Fritsch EF and Maniatis T (1989). Molecular Cloning: A Laboratory Manual. Cold Spring Harbor Laboratory Press, New York.

Scott-Craig JS, Panaccione DG, Cervone F and Walton JD (1990). Endopolygalacturonase is not required for pathogenicity of Cochliobolus carbonum on maize. Plant Cell 2: 1191-1200.

Scott-Craig JS, Cheng YQ, Cervone F, De Lorenzo G, et al. (1998). Targeted mutants of Cochliobolus carbonum lacking the two major extracellular polygalacturonases. Appl. Environ. Microbiol. 64: 1497-1503.

Shieh MT, Brown RL, Whitehead MP, Cary JW, et al. (1997). Molecular genetic evidence for the involvement of a specific polygalacturonase, P2c, in the invasion and spread of Aspergillus flavus in cotton bolls. Appl. Environ. Microbiol. 63: 3548-3552.

Teather RM and Wood PJ (1982). Use of Congo red-polysaccharide interactions in enumeration and characterization of cellulolytic bacteria from the bovine rumen. Appl. Environ. Microbiol. 43: 777-780.

Ten Have A, Mulder W, Visser J and van Kan JA (1998). The endopolygalacturonase gene Bcpg1 is required for full virulence of Botrytis cinerea. Mol. Plant Microbe Interact. 11: 1009-1016.

Ter Braak CJF and Šmilauer P (2002). CANOCO Reference Manual and CanoDraw for Windows User's Guide: Software for Canonical Community Ordination. Version 4.5. Microcomputer Power, Ithaca.

Timmer LW (1999). Diseases of Fruit and Foliage. In: Citrus Health Management (Timmer LW and Duncan LW, eds.). APS Press, Florida, 107-123.

Van Gent-Pelzer MPE, Van Brouwershaven IR, Kox LFF and Bonants PJM (2007). A TaqMan PCR method for routine diagnosis of the quarantine fungus Guignardia citricarpa on citrus fruit. J. Phytopathol. 155: 357-363.

Wagner F, Kusserow H and Schafer W (2000). Cloning and targeted disruption of two polygalacturonase genes in Penicillium olsonii. FEMS Microbiol. Lett. 186: 293-299.

Walton JD (1994). Deconstructing the cell wall. Plant Physiol. 104: 1113-1118.

Wattad C, Freeman S, Dinoor A and Prusky D (1995). A nonpathogenic mutant of Colletotrichum magna is deficient in extracellular secretion of pectate lyase. Mol. Plant Microbe Interact. 8: 621-626.

Yakoby N, Freeman S, Dinoor A, Keen NT, et al. (2000). Expression of pectate lyase from Colletotrichum gloesosporioides in C. magna promotes pathogenicity. Mol. Plant Microbe Interact. 13: 887-891.

Zamski E and Peretz I (1996). Cavity spot of carrots: II. Cell-wall-degrading enzymes secreted by Pythium and pathogenrelated proteins produced by the root cells. Ann. Appl. Biol. 128: 195-207. 